Colloquia Litteraria UKSW

2/3 2007

TOMASZ KORPYSZ

\title{
JULIUSZ WIKTOR GOMULICKI - NORWIDOLOG ${ }^{1}$
}

\author{
Wspótczesnym zacnym oddać cześć, \\ To jakby cześć Bożej prawicy \\ [C. Norwid, Do emira Abd el Kadera w Damaszku]
}

90-lecie urodzin Juliusza Wiktora Gomulickiego uczczono m.in. specjalną wystawą w Muzeum Historycznym m. st. Warszawy. Jej organizatorzy postawili sobie za cel przedstawienie czy też raczej przybliżenie, a wręcz jedynie zasygnalizowanie różnych obszarów działalności ówczesnego jubilata. I tu powstał niemały problem. Okazało się, że ciekawa biografia, a przede wszystkim niezwykle bogaty i równie niezwykle różnorodny dorobek JWG, jego liczne pasje i zainteresowania, którym się poświęcał - wszytko to znacznie przekracza ramy jednej wystawy. Drogą trudnych eliminacji wybrano jedynie (sic!) dwadzieścia rozmaitych „wcieleń” jubilata, rezygnując przy tym z ukazania go jako (w porządku alfabetycznym): „antykwariusza, archiwisty, badacza literatury polskiej XX wieku,

\footnotetext{
${ }^{1}$ Tekst pierwotnie został wygłoszony na spotkaniu Juliusz Wiktor Gomulicki norwidolog, varsavianista, bibliofil, które odbyło się 13 czerwca 2007 r. w Muzeum Literatury im. Adama Mickiewicza w Warszawie.

W tym miejscu, odnosząc się do tytułu szkicu, pozwolę sobie na wątek osobisty. Juliusz Wiktor Gomulicki wyraźnie rozróżniał prawdziwych znawców twórczości Norwida norwidologów, początkujących badaczy - norwidystów oraz wszystkich innych autorów, którzy życiem i twórczością Norwida zajmują się tylko marginalnie, przygodnie. Niedługo po naszym pierwszym spotkaniu, na egzemplarzu jednej ze swoich książek napisał mi następującą dedykację: „Drogiemu Panu Tomaszowi Korpyszowi, już norwidyście, a w przyszłości (oby!) norwidologowi”. Nie wiem, czy swoimi dotychczasowymi pracami i publikacjami poświęconymi Norwidowi zasłużyłbym już na to, aby JWG nazwał mnie norwidologiem, niewątpliwie jednak należę do tych, których w latach międzywojennych z nieco ironicznym dystansem nazywano „klanem norwidystów” i dlatego czuję się upoważniony do tego, aby w tym miejscu przypomnieć postać największego norwidologa.
} 
badacza życia literackiego i obyczajów, biografa, bibliografa, czytelnika (namiętnego!), epistolografa (nierychliwego, ale jakże interesującego), gawędziarza, grafologa, literata, mediewisty, kinomana, kolekcjonera, kryminalistyka, polemisty, polihistora, polonisty, prelegenta, szopenisty, uczonego..." ${ }^{\prime}$. I tak powstała wystawa Zygzakiem przez JWG czyli Dwadzieścia wcielen 90-latka Juliusza Wiktora Gomulickiego na przyktadzie jego wtasnych publikacji oraz ksiażek, druków ulotnych, pocztówek i fotografii ze zbiorów 25 bibliofilów i kolekcjonerów warszawskich, którą można było zwiedzać od 18 października do 21 listopada 1999 roku³.

Jakie wcielenia Juliusza Wiktora Gomulickiego znalazły się na tej wystawie? Oto one: I. Rzecznik ojca; II. Eksprawnik; III. Badacz polskiego oświecenia; IV. Badacz literatury polskiej XIX w.; V. Norwidolog-badacz; VI. Norwidolog-edytor; VII. Komparatysta i tłumacz poezji; VIII. Eseista; IX. Portrecista; X. Szpargalista; XI. Recenzent-erudyta; XII. Edytor; XIII. Antologista; XIV. Redaktor; XV. Bibliofil. Biblioman. Prasoznawca; XVI. Varsavianista; XVII. Teatrolog; XVIII. Filokartysta; XIX. Wystawiennik; XX. JWG „osobny”.

Jak widać, w tym z konieczności wybiórczym zbiorze dziedzin zainteresowań JWG dwie związane są z osobą i twórczością Cypriana Norwida. Na wystawie zaprezentowano przy tym jedynie 35 publikacji z - co warte szczególnego podkreślenia i budzi zarówno podziw, szacunek, jak i zdumienie, a nawet po prostu zazdrość ponad 300 szkiców biograficznych, interpretacji, komentarzy, polemik, wstępów, dodatków krytycznych i opracowań, które Juliusz

\footnotetext{
${ }^{2}$ Zygzakiem przez JWG czyli Dwadzieścia wcieleń 90-latka Juliusza Wiktora Gomulickiego na przyktadzie jego wtasnych publikacji oraz ksiązek, druków ulotnych, pocztówek i fotografii ze zbiorów 25 bibliofilów i kolekcjonerów warszawskich [katalog wystawy], Warszawa 1999, s. 5.

${ }^{3}$ Tytuł wystawy nawiązywał do tytułu ponadsiedmiusetstronicowego tomu różnorodnych tekstów JWG (zob. Juliusz Wiktor Gomulicki, Zygzakiem. Szkice, wspomnienia, przektady, Warszawa 1981). Nawiązywał on też jednak do sposobu pracy bohatera wystawy: „Po wszystkich tych kręgach zainteresowań, zarówno wymienionych przez nas, jak i wielu jeszcze innych, tu przemilczanych, JWG zawsze poruszał się i nadal porusza zygzakiem, który to „zygzak” nie oddaje bynajmniej jakichś „bachusowych” kroków badacza, lecz jest po prostu linią łamaną odzwierciedlającą drogę, po jakiej przechodzi on od tematu do tematu, przy czym w wędrówce tej wiele $z$ takich tematów, chociaż bliskich mu i nęcących, przeskakuje, pomija, dążąc do jednego z góry zamierzonego. Nierzadko też z nagła zmienia albo sam przedmiot swych zainteresowań, albo tylko ich obiekt" (Zygzakiem przez JWG czyli..., op. cit., s. 5).
} 
Wiktor Gomulicki poświęcił autorowi Promethidiona. Tych 300 tekstów, w większości niestety rozproszonych po rozmaitych, dzisiaj często trudno dostępnych czasopismach i tomach, a zwłaszcza wiele (ok. czterdziestu!) wyborów pism Norwida sprawiło, że w świadomości wcale niemałej grupy współczesnych czytelników i badaczy jawi się on przede wszystkim właśnie jako wybitny norwidolog. I rzeczywiście był wytrawnym norwidologiem, największym znawcą życia i dzieła poety, a tego, co zrobił dla obecności Norwida w obiegu czytelniczym oraz dla jego popularyzacji, nie sposób opisać w krótkim szkicu.

W tym miejscu warto przypomnieć, jak zaczęła się wieloletnia, jak sam przyznawał, pasjonująca przygoda JWG z Norwidem. Początki związane są, rzecz jasna, z osobą jego ojca. Wiktor Gomulicki był nie tylko znanym pisarzem i poetą, lecz także varsavianistą, kolekcjonerem i bibliofilem - właścicielem pokaźnej domowej biblioteki oraz licznego zbioru dokumentów, rękopisów i autografów. To ojciec podsuwał młodemu JWG pierwsze lektury ${ }^{4} \mathrm{i}$ to właśnie z wieloma cymeliami z księgozbioru ojca JWG zetknął się już jako dziecko. Jak sam wspomina:

\footnotetext{
${ }^{4}$ JWG po latach wspominał: „To ojciec [...], gdy ukończyłem siedem lat, obdarowywał mnie kolejno zgrabnymi tomikami Biblioteki Klasyków Polskich Wendego, a więc udatnie opracowanymi wyborami tekstów Reja, Kochanowskiego, Górnickiego, Modrzewskiego, Orzechowskiego i Klonowica, co ważniejsze zaś: Sępa Szarzyńskiego, który - o dziwo! - stał się już wtedy moim ulubionym poetą staropolskim. To ojciec również dawał mi do czytania wybrane utwory Mickiewicza i Słowackiego, a także ,gotyckie" opowiadania Krasińskiego oraz Don Kiszota w kilkutomowej edycji Biblioteki Dziet Wyborowych. To on wreszcie, gdy miałem już dziewięć lat, włożył mi do ręki gruby tom Dzieł dramatycznych Szekspira, polecając przeczytać jedynie Burzę, ale z pobłażliwością obserwując, jak po skończeniu Burzy zabrałem się do lektury wszystkich innych utworów, które znajdowały się w owym podwójnym tomie" (Juliusz Wiktor Gomulicki, Moja droga do literatury i nauki [przemówienie wygłoszone 19 maja 1983 roku we Wrocławiu z okazji promocji autora na doktora honoris causa Uniwersytetu Wrocławskiego], [w:] tenże, Aleje czarów. Spacery, sylwety, zagadki i zwierzenia literackie, Warszawa 2000, s. 332-333; pierwodruk: "Kronika Warszawy” 1994, nr 2, s. 9-16). W innym miejscu, wspominając raz jeszcze książki podsuwane przez ojca, a zwłaszcza dzieła Szekspira, wyznawał: „ta właśnie lektura Szekspira, którą kontynuowałem przez cały rok po zgonie ojca, przeczytawszy wtedy wszystkie dwanaście tomów jego dzieł w tłumaczeniu Ulricha, nie tylko wywarła zupełnie wyjątkowy wpływ na mój stosunek do literatury i w ogóle do tradycji historycznej, ale również w bardzo poważnej mierze uformowała moje późniejsze zainteresowania, a nawet całą moją osobowość, tak podatną wówczas na tego rodzaju podniety". (Najważniejsze być niezależnym [z Juliuszem Wiktorem Gomulickim rozmawia Wojciech Wiśniewski], [w:] Juliusz Wiktor Gomulicki, Aleje czarów..., op. cit., s. 343; pierwodruk: W. Wiśniewski, Lekcja polskiego, Warszawa 1993).
} 
Pismo Kraszewskiego poznałem już jako sześciolatek, ponieważ po naszej przeprowadzce $\mathrm{z}$ Mariensztatu na Litewską, kiedy ojciec ponownie ustawiał swoje książki w szafach i na regałach, parokrotnie pomagałem mu, wyjmując z pak ich poszczególne tomy. Otóż dwa takie nieduże, ale grube tomy miały na grzbiecie nalepkę z ręcznym napisem Krzyżacy. «Czy to Sienkiewicza?» - zapytałem go wtedy. «Nie, Kraszewskiego, ale zajrzyj do środka». Zajrzałem i przekonałem się, że to był oprawiony w formie książkowej rękopis nie znanej mi wtedy powieści Kraszewskiego. [...] Rękopis Kraszewskiego był chyba moim pierwszym spotkaniem z autografem znakomitego pisarza, już jednak na jesieni 1919 roku, w kilka miesięcy po zgonie ojca, przeżyłem swoją największą przygodę rękopisową. Wszedłem mianowicie w posiadanie nie tylko kilkudziesięciu rękopisów ojca, ale także paruset rękopisów z jego zbiorów (głównie listów i dokumentów z XVII-XVIII wieku) oraz paru tysięcy skierowanych do niego listów, przeważnie w sprawach literackich. Cóż to była za radość, kiedy w tej korespondencji odnajdowałem listy takich znanych mi z lektury albo ze słyszenia pisarzy, jak Bałucki, Deotyma, Dygasiński, Faliński, Gawalewicz, Konopnicka, Orzeszkowa, Prus czy Sienkiewicz 5 .

Przypomnę, że rzecz dzieje się w roku 1919, a więc te wszystkie rękopisy ze zbiorów ojca ogląda, czyta i porządkuje dziesięciolatek... Trzy lata później matka JWG, uznawszy, że może to już zrobić, przekazała mu kilka tek specjalnie przeznaczonych dla niego przez ojca jeszcze za życia autora Wspomnień niebieskiego mundurka. Wśród nich była też teka norwidowska zawierająca m.in. kilka rzadkich pierwodruków, jeden oryginalny rysunek poety, jego fotografie oraz liczne wycinki, wypisy i kopie. JWG po wielu latach, wspominając wrażenia z tych pierwszych lektur, swoje ówczesne skojarzenia i odczucia, pisał:

Wszystko to parokrotnie wówczas przeczytałem: tekst po tekście i zdanie po zdaniu, i jedne, i drugie bowiem były tak odmienne od tego, co już znałem z dziewiętnastowiecznej literatury polskiej, że zatrzymywały przy sobie oczy młodziutkiego czytelnika, oczarowane taką innością”.

\footnotetext{
${ }^{5}$ Juliusz Wiktor Gomulicki, Kępa niezapominek. Przygoda z zagadkowym rękopisem Norwida, Podkowa Leśna 1996, s. 8-9.

${ }^{6}$ Ibidem, s. 10. Dalej pisał: „Gdyby [...] nie czarodziejska teczka ojca, nigdy może nie zbliżyłbym się do Norwida $\mathrm{i}$ nie został $\mathrm{w}$ następstwie jego żarliwym czytelnikiem i wielbicielem" (ibidem, s. 11).
} 
I znów podkreślę, że tę fascynację twórczością Norwida - tak odmienną od dotychczas przeczytanych dzieł literackich - przeżywał chłopiec 13-letni...

Ta pierwsza, właściwie jeszcze dziecięca fascynacja szybko przerodziła się w prawdziwą pasję. JWG zaczął wyszukiwać i czytać inne dzieła autora Promethidiona oraz wszystko, co było z nim związane, i kupować pierwsze tomy jego poezji (wydawane m.in. przez Romana Zrębowicza i Stanisława Cywińskiego). Odnajdował też z pewnym zaskoczeniem, ale i radością - kolejne norwidiana swego ojca i przekonywał się powoli, że to właśnie Wiktor Gomulicki powinien być uznany za prawdziwego „odkrywcę” Norwida ${ }^{7}$. Kiedy zaś zapoznał się z wydanymi przez Zenona Przesmyckiego Miriama Ineditami poety, a także z osławioną edycją Tadeusza Piniego, postanowił pójść w ślady wielkich poprzedników - edytorów i badaczy twórczości Norwida. W pięknym szkicu Moja czarodziejska Mazowiecka, wspominając swoje częste zakupy książkowe w księgarni Jakuba Mortkowicza, wyznawał:

Stamtąd [...] pochodzily [...] dwie „arcydzielne” edycje dzieł Norwida: wspaniale skomentowane przez Miriama Poezje wybrane, które kupiłem w roku 1933 [...] i trzy tomy bezcennych Ineditów, które zdobyłem - jako jeden z pierwszych nabywców - w styczniu 1934 roku. Oto właśnie, jak otworzyła się przede mną, na pół wieku, wyboista i gęsto zarosła (również cierniami), dzisiaj zaś karawanna już, d rog a norwid owska.

W jednym z wywiadów na pytanie, dlaczego tyle lat swego życia (ok. 70!) poświęcił właśnie Norwidowi, JWG stwierdził:

Przecież jestem synem „Odkrywcy” Norwida, a przez kilkanaście miesięcy byłem również gościem i rozmówcą jego „Wskrzesiciela” Miriama-Przesymckiego, realizuję więc po prostu pozostawiony mi przez

${ }^{7}$ Przywracaniu ojcu należnego miejsca w historii odkrywania twórczości Norwida poświęcił JWG wiele starań. Przez lata przypominał o tym, że to właśnie Wiktora Gomulickiego należy uznać za prawdziwego „odkrywcę” Norwida, natomiast Zenona Przesmyckiego (którego zwykle tym mianem się opatruje) traktować powinno się jako „wskrzesiciela" poety. Najobszerniejszy szkic na ten temat, przywołujący wiele wypowiedzi Wiktora Gomulickiego o Norwidzie, opublikował w roku 2003 (zob. Juliusz Wiktor Gomulicki, Pierwszy „odkrywca” wielkości Norwida (Norwidowska podróż Wiktora Gomulickiego), [w:] Norwid z pespektywy poczatku XXI wieku, pod red. Janusza Rohozińskiego, Pułtusk 2003).

${ }^{8}$ Juliusz Wiktor Gomulicki, Moja czarodziejska Mazowiecka, [w:] tenże, Aleje czarów...., op. cit., s. 21 [pierwodruk: Moja Mazowiecka, „Nowe Książki” 1989, nr 9, s. 1-4]. 
nich testament norwidowski. Wychowałem się, mówiąc nawiasem, pod Szyndlerowskim portretem Norwida śpiacego, a kiedy ukończyłem 10 lat oczarowały, mnie dwa wiersze Norwida, które odnalazłem w resztkach powierzonej mi wtedy ojcowskiej teczki norwidianów".

Realizowanie owego testamentu rozpoczęło się bardzo wcześnie. Dwudziestokilkuletni czytelnik Norwida i początkujący zbieracz norwidianów postanowił przede wszystkim zapoznać się ze wszystkimi rękopisami autora Assunty, które były wówczas dostępne w Warszawie. Pisał po latach:

Na pierwsze z nich, a mianowicie na jeszcze nie opublikowane listy Norwida do Teofila Lenartowicza, natknąłem się, idąc śladami Miriama, w Bibliotece Krasińskich. Po raz pierwszy w życiu dotykałem wtedy (1934) kart zapisanych przez samego poetę, którego pismo znałem do owego czasu jedynie z faksymiliów ogłoszonych przez Miriama. Wielkie to było święto - i dla ducha, i dla wyobraźni, a także dla mojej, liczącej już prawie piętnaście lat, pasji rękopiśmienniczej. Pośród owych listów znalazłem również miniaturę literacką o charakterze satyrycznym, Dwie powieści (1866), którą opublikowałem wkrótce w „Pionie” (1935), zaczynając nią długi i jeszcze nie dokończony (ale d. c. n.) szereg ogłoszonych przez siebie ineditów Norwida" ${ }^{10}$.

Już wtedy początkujący badacz i edytor zaczął myśleć o zdobyciu jakiegoś autografu na własność. Wiosną 1943 roku w antykwariacie Zofii Potockiej „Miniatura” kupił wreszcie autografy dwu wierszy amerykańskich z 1854 roku: Moja piosnka [II] oraz Rzeczywistość i marzenia (!). Oba wprawdzie spłonęły w czasie powstania warszawskiego w gruzach domu JWG, który stracił wówczas cały swój pierwszy księgozbiór, ale w latach późniejszych udało mu się zdobyć jeszcze kilka innych autografów poety - zarówno krótkich, niezbyt czytelnych notatek, jak i kolejnych redakcji wierszy. Wszystkie po latach opublikował, kilka sprzedał, kilka zaś ofiarował różnym instytucjom i osobom prywatnym - m.in. brulionową wersję jednego z papieskich, a raczej watykańskich wierszy Norwida ( $\mathrm{Na}$ smętne wieści z Watykanu) podarował Janowi Pawłowi II.

\footnotetext{
${ }^{9}$ Obowiazki i przyjemności. Z Juliuszem Wiktorem Gomulickim rozmawiają Andrzej Bernat i Tomasz Łubieński, „Nowe Książki” 2001, nr 1, s. 6.

${ }^{10}$ Juliusz Wiktor Gomulicki, Kępa niezapominek..., op. cit., s. 12.
} 
Przypomniałem tu, jak sądzę, nie wszystkim znane początki norwidologicznej pasji Juliusza Wiktora Gomulickiego, aby podkreślić, jak wcześnie się ona zaczęła i z jaką intensywnością niemal od razu zaczęła być realizowana. Jeszcze przed wojną dwudziestokilkuletni JWG opublikował kilka szkiców na temat Norwida (pierwsze w roku 1935) - a właściwie Norwidów, początkowo pisał bowiem również o Ludwiku - oraz kilkanaście ineditów. W czasie wojny, w przededniu powstania warszawskiego, a więc 31 lipca 1944 roku wydał w 350 egzemplarzach dziś będący białym krukiem zbiorek 30 nieznanych, pozostających dotąd $\mathrm{w}$ rękopisach lub rozproszonych tekstów Norwida zatytułowany Gromy $i$ pytki, którego jeden z egzemplarzy zdążył jeszcze ofiarować Zenonowi Przesmyckiemu. W latach późniejszych tego rodzaju rozmaite znaleziska i odkrycia norwidowskie drukował jeszcze wielokrotnie. Znakomita większość ineditów poety, jakie ukazały się po wojnie, została opublikowana właśnie przez JWG. Ostatnie to wydane w 1999 r. przez Muzeum Literatury w bibliofilskim nakładzie 200 numerowanych egzemplarzy trzy teksty filozoficzne i przekład z Platona ${ }^{11}$ oraz dwie notatki, które ukazały się w roku $2001 \mathrm{w}$ dwu czasopismach literackich ${ }^{12}$. Kolejne edycje nieznanych tekstów Norwida wiązały się z wieloletnią pracą nad odczytywaniem jego często bardzo mało czytelnych rękopisów. JWG (przez wielu podziwiany za talent „grafologiczny”) wykonał tytaniczny trud ustalenia kanonicznej postaci wielu tekstów, które były znane z odpisów czy wersji brulionowych, odczytał też wiele tych wyrazów i wyrażeń, a wręcz całych tekstów, z którymi nie poradzili sobie wcześniejsi edytorzy, łącznie z Zenonem Przesmyckim. Przykładem mogą być fragmenty przekładu Odysei, wiersz Nie myśl, nie pisz, którym zachwycał się Kazimierz Wyka ${ }^{13}$ czy komedia Hrabina Palmyra, która w ołówkowym brudnopisie dochowała się w papierach po Miriamie, ale której ten nigdy nie odczytał. Innym przykładem jest tragedia Kleopatra, której jedna ze scen, jak pisze JWG, ,jest w autografie prawdziwym palimpsestem"14.

\footnotetext{
${ }^{11}$ Zob. Cyprian Norwid, Inedita. Trzy teksty filozoficzne i przektad z Platona. Wydał z autografu Juliusz Wiktor Gomulicki, Warszawa 1999.

${ }^{12}$ Zob. Z ineditów Cypriana Norwida. Protestantyzm, „Nowe Książki” 2001, nr 1, s. 4, Bizancjum, „Twórczość” 2001, nr 9, s. 3-5.

${ }^{13}$ Zob. Kazimierz Wyka, Na początku byly linie, „Odrodzenie” 1948, nr 42.

${ }^{14}$ Juliusz Wiktor Gomulicki, Wstep, [w:] Cyprian Norwid, Okruchy poetyckie i dramatyczne. Zebrał i opracował Juliusz Wiktor Gomulicki, Warszawa 1956, s. 14.
} 
Wydawanie nieznanych tekstów Norwida to tylko jeden - choć przecież niezwykle istotny - aspekt norwidologicznej działalności Juliusza Wiktora Gomulickiego. Był on też przecież niezrównanym komentatorem i interpretatorem twórczości autora Rzeczy o wolności stowa. Opublikował wiele niezwykle cennych studiów i szkiców, wielokrotnie wykorzystując je m.in. jako wstępy lub posłowia do wydawanych przez siebie wyborów tekstów Norwida. Potrafił toczyć wieloletnie, poparte niezwykle drobiazgowymi studiami polemiki - nawet o tak z pozoru drobne kwestie jak szczegółowe emendacje, niewłaściwe odczytania choćby jednej litery. Przykładem może być tu szkic Walka z Belzebubem. O jedna litere w „Tęczy” Norwida ${ }^{15}$, opublikowany w 1966 roku. Tekst ten doczekał się polemik, na które JWG błyskawicznie zareagował kolejnym szkicem: Jeszcze o jednej literze $w$,Tęczy” opublikowanym w tym samym $1966 \mathrm{roku}^{16}$. O tym, że dawny problem był dla autora wciąż żywy, świadczy dopisek z roku 2000, którym opatrzył on jeden z tych tekstów, przygotowując go do druku w tomie Aleje czarów ${ }^{17}$. Takich przykładów jest znacznie więcej.

Wielokrotnie JWG poprawiał błędy poprzedników i weryfikował wcześniejsze ustalenia dotyczące np. autorstwa tekstów i rysunków. Już w 1935 roku przekonująco dowiódł, że jeden z liryków, przypisywany Norwidowi przez Miriama i Kaczorowskiego, w rzeczywistości wyszedł spod ręki innego poety. Niemało takich ustaleń poczynił również w późniejszych latach, często był proszony przez Bibliotekę Narodową czy różne muzea o konsultacje w sprawie autentyczności rozmaitych norwidianów i pseudonorwidianów. Wiele jest również różnego typu zagadek interpretacyjnych, które JWG rozwiązał w swoich bogatych, niezrównanych komentarzach. Komentarze te mimo niezwykłego rozwoju norwidologii w ostatnich latach i wręcz ogromnej liczby różnego typu prac poświęconych Norwidowi, które się w tym okresie ukazały - wciąż pozostają niezastąpione dla każdego czytelnika i badacza. Owszem, zdarzają się tam miejsca niewyjaśnione, zdarzają się nie dość mocno udokumentowane tezy i hipotezy, zdarzają się wręcz nawet nadinterpretacje i oczywiste pomyłki,

\footnotetext{
${ }^{15}$ Juliusz Wiktor Gomulicki, Walka z Belzebubem. O jedna literę w „Tęczy” Norwida, „Współczesność” 1966, nr 8.

${ }^{10}$ Juliusz Wiktor Gomulicki, Jeszcze o jednej literze w „Tęczy”, „Współczesność” 1966, nr 13.

${ }^{17}$ Zob. Juliusz Wiktor Gomulicki, Jeszcze o jednej literze w „Tęczy”, [w:] tenże, Aleje czarów...., op. cit., s. 244-245.
} 
ale nie sposób sobie wyobrazić rzetelnej pracy norwidologicznej, która by pełnymi garściami nie czerpała z bogactwa komentarzy JWG. Choćby z jego ustaleń biograficzno-faktograficznych. Norwid, tak silnie zanurzony w otaczającym go świecie, tak żywo - także literacko reagujący na to, co się wokół niego działo, nie może być zrozumiany bez znajomości realiów i faktów epoki. I tu JWG oddał pokoleniom norwidologów nieocenione usługi. To on przecież ustalił wiele wcześniej nieznanych faktów z biografii poety, odtworzył jego podróże, spotkania, znajomości i kontakty. To on dotarł do wielu źródeł i inspiracji utworów Norwida, to on wskazał na liczne pomocne, a czasem wręcz niezbędne do zrozumienia pism poety konteksty kulturowe. Często zarzucano JWG zbytni biografizm w czytaniu Norwida. I rzeczywiście niejednokrotnie szedł za daleko w jednostronnej biograficznej lekturze jego pism. Ale przecież - jak pisał sam Norwid „Dobrze jest miewać wzgląd na autora, / Kiedy się czyta” (III) ${ }^{18}$. Nie da się - tu mówię także w swoim imieniu, a niezgodnie z niektórymi współczesnymi metodologiami i tendencjami lekturowymi - nie da się dobrze zrozumieć tekstu w oderwaniu od jego autora, realiów powstania, szeroko rozumianego kontekstu kulturowego. Takich właśnie, licznych wielowątkowych i erudycyjnych kontekstów prace JWG dostarczały i nadal dostarczają. Wystarczy tu wymienić choćby wciąż niezastąpiony ponadtrzystustronicowy przewodnik po życiu i twórczości Norwida wydany jako 11. tom Pism wszystkich oraz jako druk osobny ${ }^{19}$ i zawierający m.in. liczne reprodukcje dzieł plastycznych autora Wędrownego sztukmistrza. Należy tu przy tym podkreślić, że komentarze JWG odsyłają nie tylko do innych tekstów kultury, wydarzeń, osób czy miejsc. Są one także niezastąpione we wskazywaniu autocytatów, autokomentarzy i wewnętrznych nawiązań istniejących w samej twórczości Norwida. Edytor niezawodnie pokazuje czytelnikowi, gdzie jeszcze dany motyw, dana metafora, a nawet dane słowo się pojawia, w jakim kontekście, z jakim ładunkiem semantycznym i wartościowaniem, jakie może to mieć znaczenie itd. Wskazywanie takich dialogicznych nawiązań bardzo ułatwia badanie twórczości Norwida, śledzenie obecnych w niej tematów i wątków.

\footnotetext{
${ }^{18}$ Cyt. za: Cyprian Norwid, Pisma wszystkie. Zebrał, tekst ustalił, wstępem i uwagami krytycznym opatrzył pracował Juliusz Wiktor Gomulicki, tom 1-11, Warszawa 1971-1975.

${ }^{19}$ Zob. Juliusz Wiktor Gomulicki, Cyprian Norwid. Przewodnik po życiu i twórczości, Warszawa 1976.
} 
Publikowanie ineditów, odczytywanie zdawałoby się nieczytelnych fragmentów rękopisów, ustalanie ostatecznych lekcji, docieranie do źródeł i inspiracji, szukanie wielorakich powiązań i nawiązań, interpretowanie i komentowanie - wszystko to zapewniłoby Juliuszowi Wiktorowi Gomulickiemu trwałe miejsce w norwidologii. Ale przecież jest coś jeszcze, coś zupełnie podstawowego - dbanie o stałą obecność pism Norwida w obiegu czytelniczym $^{20}$. JWG podjął dzieło rozpoczęte przez Miriama i przez lata starał się o to, aby kolejne wybory pism poety były stale dostępne na rynku księgarskim. Jak sam pisał, chciał przyczynić się do tego, aby rozerwać krąg milczenia wokół poety „milczenia, które jest krzywdą wyrządzoną nie tylko jednemu spośród naszych największych poetów narodowych, ale także szerokim rzeszom miłośników wielkiej poezji - poezji prawdy i obowiązku, poezji dziejów człowieka"21. Niedługo po wonie opracował i wydał m.in. kilka popularnych wyborów tekstów Norwida, w tym edycje Vade-mecum (1962), Trylogii wtoskiej (1963) i Legend (1964). Dążył też do tego, aby opublikować pełne wydanie krytyczne pism Norwida. Przygotowania do takiego wydania trwały przez wiele lat. Jeszcze w roku 1952 JWG wszedł w skład komitetu redakcyjnego, który na Katolickim Uniwersytecie Lubelskim, pod przewodnictwem Stanisława Pigonia, miał taką edycję przygotować. Rzecz jednak wówczas nie doszła do skutku, a od tamtego czasu datuje się swego rodzaju konflikt między JWG a innymi norwidologami i jego dystansowanie się wobec oficjalnego życia naukowego, które spowodowało, że podjął on samodzielne starania o krytyczną edycję pism Norwida. W roku 1956, jako cząstkowy efekt tych prac, ukazał się tom Okruchy poetyckie $i$ dramatyczne, w którym znalazło się wiele nieznanych lub zapomnianych utworów Norwida z bogatym, sześciokrotnie obszerniejszym od części tekstowej aparatem krytycznym i komentarzami edytora. Dziesięć lat później ukazały się entuzjastycznie przyjęte przez badaczy i krytyków literacki-

\footnotetext{
${ }^{20}$ JWG przypominał także Norwida - artystę; był on m.in. inicjatorem i współorganizatorem kilku wystaw, na których prezentowano nie tylko rękopisy tekstów Norwida czy różnorodne edycje jego pism, lecz także rysunki, akwarele i inne dzieła plastyczne.

${ }^{21}$ Juliusz Wiktor Gomulicki, Wstęp, [w:] Cyprian Norwid, Okruchy poetyckie i dramatyczne, op. cit., s. 6 .

${ }^{22}$ Zob. głosy cytowane w: Cyprian Norwid, Pisma wszystkie, op. cit., t I, s. XXIX.
} 
$\mathrm{ch}^{22}$ dwa pierwsze tomy projektowanej edycji krytycznej ${ }^{23}$. Tom pierwszy obejmował blisko czterysta utworów poetyckich, obszerny wstęp, kronikę życia i twórczości Norwida oraz informacje dotyczący źródeł i zasad wydania. Tom drugi z kolei stanowiły zebrane na ponad tysiącu stronach metryki i komentarze, które do dziś pozostają najobszerniejszymi i najcenniejszymi, najczęściej wykorzystywanymi komentarzami do wierszy Norwida. Sięganie do nich pozwala wyjaśnić wiele zagadek, rozwiać wiele wątpliwości oraz uniknąć wielu pułapek czyhających na czytelników poezji Norwida. Ich znajomość pozwala też unikać wyważania dawno już otwartych drzwi, co niekiedy zdarza się w norwidologii i dziś. Niestety, dalsze tomy tej edycji nigdy nie zostały opublikowane. Juliusz Wiktor Gomulicki przygotował natomiast popularną pięciotomową edycję Pism wybranych, które po raz pierwszy ukazały się w 1968 roku $^{24}$ i stanowiły najobszerniejszy do tamtego czasu wybór utworów Norwida. Na początku lat 70. doprowadził zaś do opublikowania pomnikowego 11-tomowego wydania Pism wszystkich ${ }^{25}$. Dzięki wieloletniej pracy zgromadził wszystkie znane wówczas teksty Norwida oraz wiele jego prac plastycznych, ustalił ich postać, opatrzył niezbędnymi komentarzami. Dzięki temu odbiorcy mogli wreszcie zapoznać się już nie z kolejnymi wyborami, ale z Norwidem po norwidowsku „całym”. Nie trzeba chyba tłumaczyć co to znaczyło i nadal znaczy nie tylko dla miłośników, lecz także dla badaczy twórczości autora Qudiama. Wreszcie nie trzeba było uciekać się do niekiedy trudno dostępnych czasopism i rzadkich pierwodruków, by dotrzeć do konkretnych utworów. Wreszcie można było łatwo porównywać różne teksty i ich wersje, śledzić rozwój Norwidowskiej myśli i poetyki oraz jego języka. Pisma wszystkie nie miały wprawdzie charakteru edycji krytycznej, ale ich wartości nie sposób przecenić. Były one jednak wydawnictwem w pewnym sensie elitarnym - pokaźne (ponad 6,5 tys. stron), opublikowane jedynie raz, w niezbyt wysokim nakładzie (12780 egzemplarzy), opa-

\footnotetext{
${ }^{23}$ Cyprian Norwid, Dzieła zebrane. Opracował Juliusz Wiktor Gomulicki, t. I, Wiersze. Teksty, tom II Wiersze. Dodatek krytyczny, Warszawa 1966.

${ }^{24}$ Zob. Cyprian Norwid, Pisma wybrane. Wybrał i objasnił Juliusz Wiktor Gomulicki, Warszawa 1968.

${ }^{25}$ Zob. Cyprian Norwid, Pisma wszystkie, op. cit.
} 
trzone erudycyjnymi przypisami i komentarzami edytorskimi nie mogły dotrzeć do przeciętnego czytelnika. Juliusz Wiktor Gomulicki zdawał sobie z tego sprawę i przygotowywał kolejne wybory wierszy i szerzej - pism Norwida. Czynił tak przez całe życie, mając poczucie, że trzeba, by teksty poety miały szanse trafiać do kolejnych pokoleń czytelników. Ostatni przygotowany przez JWG wybór poezji Norwida ukazał się jeszcze w roku $2001^{26}$.

I tu miejsce na jeszcze jeden wątek. Juliusz Wiktor Gomulicki pracował nad Norwidem stale, do końca życia. Wydawać by się mogło, że po opublikowaniu Pism wszystkich mógłby poprzestać na dokonywaniu z nich rozmaitych wyborów. Tymczasem JWG kolejne edycje nawet tych samych utworów Norwida nie tylko opatrywał zmienianymi (niekiedy radykalnie), coraz bardziej rozbudowanymi wstępami i komentarzami ${ }^{27}$, lecz także je modyfikował. I nie chodzi tu po prostu o inny dobór tekstów. Edytor potrafił przyznać się do swoich błędów i je naprawić - wielokrotnie poprawiał i zmieniał swoje niegdysiejsze odczytania i ustalenia. W jednym z wywiadów przyznawał np.: „W Pismach wszystkich znajduje się [...] sto kilkadziesiąt wyrazów, których nie udało mi się odczytać do roku 1975. Tu jednak dodam, że kilkadziesiąt spośród nich już odczytałem"28. Prześledzenie różnych edycji pism Norwida przygotowanych przez JWG pozwala odnaleźć stosunkowo liczne takie zmiany. Modyfikował on jednak nie tylko swoje dawne lekcje, lecz także różnego rodzaju hipotezy. Dwa drobne konkretne przykłady - we wspomnianym wydaniu z 2001 roku kilkakrotnie w komentarzu zmienił odniesienie niektórych „kobiecych” aluzji Norwida, inaczej też zinterpretował jeden z rysunków poety, uznając go za portret Kamili Lemańskiej, a nie jak dawniej - Marii Kalergis. Inną postać nadał też znaczącemu podtytułowi jednego z wierszy ( $Z$ poktadu „Marguerity” wyptywajacej dziś do New-York), co niegdyś jedynie sugerował jako możliwość. Warto dodać,

${ }^{26}$ Zob. Cyprian Norwid, Liryki wybrane. Wybrał, ułożył i opracował Juliusz Wiktor Gomulicki, Warszawa 2001.

${ }^{27}$ Warto prześledzić np. kolejne edycje tomów Trylogia włoska czy Legendy. Na marginesie - szkoda, że jak dotąd nie został zrealizowany niegdysiejszy pomysł opublikowania w jednym tomie wszystkich wstępów JWG do Vade-mecum - byłaby to bardzo ciekawa lektura.

${ }^{28}$ Najważniejsze być niezależnym..., op. cit., s. 347. 
że są utwory, postaci i tematy związane z Norwidem, które z pasją eksplorował przez wiele lat i niejednokrotnie stawiał rozmaite hipotezy, które później weryfikował. Jednym z takich tematów był wątek pierwszej młodzieńczej miłości poety i jego obiektu - tajemniczej Kamili L. JWG przez lata nie wiedział, kim była ta dziewczyna, przez lata próbował tego dociec i modyfikował swoje kolejne ustalenia. Kiedy mu się to udało, wielokrotnie zapowiadał, że tej miłości młodego Cypriana do wspomnianej już Kamili Lemańskiej poświęci osobną książkę ${ }^{29}$. Szkoda, że nigdy ona nie powstała, na pewno byłaby pasjonującą lekturą...

Od niedawna - dzięki uprzejmości i życzliwości pani Barbary Gomulickiej i pana Maurycego Gomulickiego, którym w tym miejscu składam serdeczne podziękowania - mam możliwość obcowania z kompletem Pism wszystkich należącym niegdyś do JWG. Niezwykłe wrażenie wywołuje ogromna liczba rozmaitych dopisków, zmian i poprawek - od drobnych korekt interpunkcyjnych, przez inaczej odczytane czy wręcz pierwotnie pominięte, przeoczone wyrazy, a nawet całe frazy, aż po zmienione datacje wierszy czy listów i ustalenia ich adresatów. Tomy te to typowy przykład tzw. „książek faszerowanych" - pełno w nich fotokopii rękopisów, zdjęć, wycinków (często z międzywojennej, a nawet XIX-wiecznej prasy), karteczek z notatkami, wypisów. Poruszające jest np. to, że jednemu z listów, w którym Norwid pisze o Piusie IX towarzyszy popodkreślany przez JWG wycinek z kolorowego tygodnika z roku... 2001 także dotyczący tego papieża i opisujący go w kontekście w pewnym stopniu zbliżonym do refleksji Norwida. Ten drobny, jakże znamienny przykład daje obraz tego, z jaką skrupulatnością JWG traktował swoje dzieło i jak intensywnie przez całe życie nad nim pracował, wykorzystując przy tym wszelkie dostępne źródła. Wielokrotnie utyskiwał on zresztą na liczne błędy drukarskie, któ-

${ }^{29}$ Zob. np. O wielkiej mitości Cypriana Kamila Norwida. Z Juliuszem Wiktorem Gomulickim rozmawiaja Ewa Talacha i Mirostaw Zdrodowski, „Bocznica. Kwartalnik społeczno-kulturalny", 2001, nr 6, s. 4. Na marginesie warto zaznaczyć, że na trop Kamili Lemańskiej wpadły też osoby z poznańskiej Pracowni Kalendarza Życia i Twórczości Cypriana Norwida, które wyniki swoich poszukiwań opublikowały w roku 2000 (zob. Zofia Dambek, Zagadka „Kamilli z L. B.”, „Studia Norwidiana” 17-18 (1999-2000), s. 175-281). Z osobistych rozmów z JWG - często bardzo ostro reagującym na tych, którzy go wyprzedzali w publikowaniu czy to ineditów, czy też różnorodnych odkryć norwidologicznych - wiem, że z uznaniem przyjął tę pracę, podkreślając jej dociekliwość i rzetelność. 
rych nie uniknięto przy publikacji Pism wszystkich. Przyznawał się jednak także do swoich własnych pomyłek i przeoczeń podczas pracy nad tą edycją. To dlatego nie zgadzał się na propozycję wznowienia tego wydania, argumentując to tym, że musiałby najpierw wprowadzić bardzo wiele różnego typu zmian i poprawek. Na marginesie warto wspomnieć, że JWG był w ogóle niezwykle czuły na wszelkie błędy redaktorskie i korektorskie. W swoich tekstach (nie tylko norwidologicznych) nigdy nie omieszkał wytknąć wszelkich potknięć autorów i redaktorów - od merytorycznych, aż po interpunkcyjne ${ }^{30}$. Żywo (często krytycznie) reagował też na dokonania innych norwidologów i norwidystów. Uderzające jest to, że w jego księgozbiorze obok tomów Brockhausa, Miriama, Zrębowicza czy Cywińskiego oraz prac przedwojennych stały najnowsze publikacje poświęcone autorowi Assunty. Na wielu marginesach znaleźć przy tym można było dopiski i (niekiedy ostre i emocjonalne) komentarze JWG, a także jego poprawki. Symptomatyczna jest tu bibliografia prac norwidologicznych zamieszczona w jednym z numerów „Studiów Norwidiana” ${ }^{1}$, na której widnieje kilkadziesiąt różnego rodzaju korekt.

Juliusz Wiktor Gomulicki zrobił dla norwidologii wiele, bez jego prac ta dziedzina polonistyki na pewno nie miałaby szans na tak intensywny rozwój. Mimo to przez lata pozostawał na uboczu oficjalnego życia naukowego, zresztą - w dużej mierze $\mathrm{z}$ własnej woli i z przekonania. Nie był on też jednak dostatecznie doceniany, niekiedy, obficie korzystając z jego prac, pomijano go milczeniem i nieuwzględniano choćby w przypisach. Owszem, jego edycje zawierają wiele niekiedy bardzo dyskusyjnych arbitralnych rozwiązań (niekiedy wręcz poprawiał on Norwida, ponieważ uznawał, że po-

\footnotetext{
${ }^{30}$ Tu po raz kolejny pozwolę sobie na wątek osobisty. Mam w swoich zbiorach przygotowane przez JWG edycje tekstów Norwida, na których - kiedy poprosiłem go o dedykacje - naniósł poprawki, przeoczone w korekcie lub nieuwzględnione przez wydawców. Są tam rzeczy bardzo znaczące - np. pominięcie całego zdania w komentarzu czy też pomyłka w imieniu i nazwisku, jak i zupełnie drobne - np. nieuwzględnienie apostrofu w odmianie nazwiska obcego czy zamiana wykrzyknika na znak zapytania. JWG dopisał też komentarze, np.: „Egzemplarz z naniesionymi na jego kartach poprawkami autora, który nie widział rewizji tego tekstu” czy: „Oj, porobili wiele błędów w tym składzie". Stanowią one świadectwo skrupulatności JWG i jego szacunku dla czytelnika, dla mnie zaś są niezwykle cenną pamiątką i wzorem filologicznej akrybii.

${ }^{31}$ Zob. Edward Jakiel, Bibliografia Cypriana Norwida 1971-1980, ,Studia Norwidiana" 15-16: 1997-1998, Lublin 1999, s. 199-316.
} 
eta $\mathrm{w}$ pośpiechu się po prostu pomylił w czasie pisania), a nawet oczywistych nadużyć i pomyłek ${ }^{32}$. Owszem, niekiedy zazdrośnie strzegł on swoich różnorodnych odkryć norwidologicznych i np. przez lata nie publikował posiadanych w swoich zbiorach ineditów. Owszem, jego komentarze i interpretacje grzeszą niekiedy zbyt daleko idącym biografizmem, a także jednostronnością i kategorycznością odczytań. Owszem, potrafił dyskredytować i bardzo ostro krytykować cudze dokonania norwidologiczne, zwłaszcza o charakterze edytorskim, czego przykładem może być choćby przywoływana już Kęa niezapominek. Nie usprawiedliwia to jednak pojawiających się niekiedy w norwidologii lekceważących czy wręcz napastliwych wypowiedzi pod jego adresem. Wkładu, który JWG włożył w norwidologię i popularyzację osoby i twórczości Norwida nie sposób przecież przecenić. Za jego pasję, która trwała niemal przez całe życie, za jej efekty w postaci wielu edycji i ponad 300 tekstów, z których jeszcze przez wiele lat wszyscy będziemy korzystać, za dbałość o - jak pisał Norwid - „każdą komę i jotę”, za trud włożony w to, by Norwida przybliżyć, ale nie, mówiąc po norwidowsku, „zwulgaryzować” należy się Juliuszowi Wiktorowi Gomulickiemu uznanie, szacunek i po prostu wdzięczność nas wszystkich.

${ }^{32}$ Liczne błędne odczytania czy też pominięte w Pismach wszystkich wyrazy i wyrażenia odnaleźć można w kartotece Pracowni Słownika Języka Cypriana Norwida, a także w serii słownikowych zeszytów tematycznych - zob.: Stownik jezyka Cypriana Norwida. Zeszyt próbny, pod red. J. Chojak, J. Puzyniny, E. Teleżyńskiej, E. Wiśniewskiej, Warszawa 1988; Stownictwo etyczne Cypriana Norwida, pod red. J. Puzyniny, Warszawa 1993; E. Teleżyńska, Nazwy barw w twórczości Cypriana Norwida, Warszawa 1994; Stownictwo estetyczne Cypriana Norwida, pod red. J. Chojak, Warszawa 1994; T. Korpysz, J. Puzynina, Wolność i niewola w pismach Cypriana Norwida, Warszawa 1998; A. Kadyjewska, T. Korpysz, J. Puzynina, Chrześcijaństwo w pismach Cypriana Norwida, Warszawa 2000. Wiele takich błędów odnotowują też autorzy pierwszej krytycznej edycji Dziet wszystkich Norwida pod red. Stefana Sawickiego, którą w tym roku zapoczątkowano tomem Proza w opracowaniu Rościsław Skręta (Lublin 2007). 